\title{
Modular Spatial Structure from Sheet Material: Lucca 2018
}

\section{Modulárna priestorová štruktúra z plošného materiálu: Lucca 2018}

Jakub Novák

realizace a výstava modulární struktury v městském prostoru v rámci bienále Cartasia v italském městě Lucca, 4. srpna - 27. záŕí 2018

Fakulta architektury, Vysoké učení technické v Brně školitel: doc. Ing. arch. Jiří Palacký, Ph.D.

\begin{abstract}
The paper deals with the use of a flat medium for the creation of spatial modular structures. In the presented case history, structure made during Cartasia, The International Festival of Paper, Biennale of Contemporary Art, Lucca, Italy. I present the possibilities of use of carton industry products in an art project.
\end{abstract}

KEYWORDS: modular structure; biennale; Lucca; paper; carton; art

\begin{abstract}
ABSTRAKT: Príspevok pojednáva o použití plošného média pre vytváranie priestorových modulárnych štruktúr. Na prezentovanej kazuistike, štruktúre realizovanej počas medzinárodného bienále papierového umenia Cartasia v talianskom meste Lucca, ukazujem možnosti využitia produktov kartonárskeho priemyslu v umeleckom projekte.
\end{abstract}

KLÍČOVÁ SLOVA: modulární struktura; bienále; Lucca; papír; karton; umění 
